\title{
HESYCHASM AS A WAY TO THEOSIS IN PHILOSOPHICAL AND RELIGIOUS VIEWS OF REPRESENTATIVES OF THE UKRAINIAN MIDDLE AGES
}

\section{Hudzenko O.}

\section{INTRODUCTION}

The search for answers to questions about the meaning of life, as well as ways of self-improvement are certainly inherent in man in different historical epochs. Therefore, scholars often consider the always pressing problems of achieving the end result of spiritual formation, for example, by gaining a mystical experience by the faithful of the Christian church. Also, the study of the role of hesychasm in the formation of the spiritual culture of the Ukrainian Middle Ages is important for identifying the peculiarities of the formation of national spiritual values. Realizing this, many researchers turned to this topic (V. Gorsky, S. Bondar, N. Nikitenko, N. Zhirtueva, V. Kushakov, A. Tykholaz, J. Stratiy, M. Kashuba, I. Zakhar, T. Chaika, A. Golub, N. Naumova, V. Paterikina, T. Gorbachenko, N. Vereshchagina, etc.).

In particular, the question of the role of hesychasm in achieving theosis is devoted to scientific research of the following scientists: V. Babiy considers the Christological and pneumatological aspect of the doctrine of theosis in the works of St. Simeon the New Theologian (Babiy, 2013), E. Chornomorets reveals the theoretical foundations of Christian-Neoplatonic aesthetics of Maximus the Confessor (Chornomorets, 2019), A. Glushchenko reveals the significance of the anthropology of St. Maximus the Confessor for modern Orthodox apologetics (Hlushchenko, 2013), G. Nenya explores mystical experience and practice in the concept of deification in the context of historical and philosophical analysis of the tradition of hesychasm (Nenya, 2007), O. Lysenko establishes essential characteristics favor light as the meaning of the Orthodox ideal of man (Lysenko, 2016). Scientific research has considered spirituality as a philosophical and theological category, related to various aspects of philosophical culture, but this problem remains relevant. In particular, one of the little-studied aspects is the role of medieval hesychasm in the formation of spiritual values of Ukrainians.

The purpose of the study, from which its tasks follow, is to analyze the search for ways to reflect a person on his essence through hesychasm in the context of the concept of deification (theosis). The scientific novelty of the study lies in the focus of our research on the Christian-anthropological views of the representatives of philosophical and religious thought of the Ukrainian Middle Ages. This investigation is based on a religious approach to the study of historical and philosophical problems. We also used the following methods: 
textual, systematization and logical generalization of information from primary sources and other research material, comparative-historical in connection with the analysis and interpretation of texts. We were also guided by the principles of confessional disengagement, objectivity and historicism.

\section{Hesychasm as the embodiment of the Christian idea of deification}

It should be emphasized that hesychasm, as a specific branch of GrecoByzantine Christian theology, illustrates more than a thousand years of practice and theological theory of the development of a religious-ideological concept based on the idea of deification of the human being.

Among the Christian writers of the East, the Hellenic trend, founded by Origen and Gregory of Nyssa, for a long time, tended to reconcile the Christian faith with the Greek philosophical sciences. Gregory of Nyssa argued that in order to achieve «smart light», you need focused prayer, through which the mind renounces everything, then the power of the Holy Spirit allows a person to see the indescribable and immeasurable Beauty. Revealing God as Beautiful, Gregory of Nyssa notes that in the created world everything is only involved in the idea of beauty. Spiritual beauty surpasses visible beauty. Thus, only the divine, intelligible world (the world of spiritual beings) is recognized as truly existing (Predko, 2005).

According to the concept of hesychasm, each person during his life is called to realize the real state of his existence. In particular, to perceive and learn to distinguish its three components: body, soul and Spirit, as well as to see the deepest essence in your heart. Accordingly, she must make her own choice: to direct all thoughts, actions and forces to spiritualization, or deification of the body. Therefore, the human body, according to the teachings of Gregory Palamas, can be a carnal body, a soully body, and a spiritual body.

The holistic essence of hesychastic practice indicates that the mystical experience is considered the highest spiritual state of man, which is consciously and gradually achieved by him in the process of life. In this case, consciousness is the main anthropological factor that determines the nature of the interaction of anthropological processes, their development and synthesis. It forms an inner unity in man himself, which, trying to learn about the world around him, combines intellectual and moral efforts (Telizhenko, 2002).

Note that hesychastic mystical-spiritual practice appeared as a two-tier structure of the spiritual ascent of the individual to his integrity. Asceticism and mysticism were part of the same process associated with different levels of organization of hierarchical semantic systems that characterize man's relationship to God, nature, to the transcendent world (Nenya, 2006). Hesychastic spiritual practice also consisted of elements of cognitive activity related to the study of sacred texts and mystical activities aimed at prayerful and psychophysiological transformation of the individual's own condition and the acquisition of anthropological integrity as a problem of overcoming the rupture of human existence (Zuban, 2008). 
The anthropological basis of hesychastic practice consists of individual experiences and conscious change of the inner state of man, due primarily to mental and emotional processes that can cause changes in the physical state of man and contribute to anthropological integrity as energy-semantic unity of all human processes. The latter in Christian practice are associated with many energies as the beginning of human existence or spirituality. Absolutely coordinated interaction of all anthropological processes in a person open to the perception of the world around him can cause an anthropological transformation of a holistic nature, a change in the way he thinks and perceives the world around him. Achieving anthropological integrity is the main task of the practitioner, which corresponds to the top of practice - the acquisition of mystical experience (Telizhenko, 2004).

It follows that hesychastic practice is aimed at the internal harmonization of the human personality by harmonizing the activities of the heart, body and mind.

Thus, hesychasm embodies the specific use of spiritual and mystical experience in the practice of developing theological theory. Mystical concepts and symbolism of uncreated light, divine energies in the practice of deification as a certain ideal direct the direction of theological and prayer activities aimed at forming or restoring the integral structure of the human being, which in modern historical-philosophical and philosophical-scientific literature received the definition of anthropological-synergistic synthesis (Zuban, 2008).

\section{The role of hesychasm in achieving theosis}

The basis of the hesychastic anthropological concept was the ontological principle of the need for theosis, which was a core element in its axiological system, focused on the search for a kind of synthesis of worldview of the individual and the worldview of society as a whole.

Note that theosis is a transformation and transcendence of anthropological reality, an actual ontological transformation (Khoruzhiy, 2005: 186). His mysticism and asceticism is hesychasm. In it, theosis (deification) is seen as a state of subjective experience of the human person. This is a gradual path of spiritual ascent, the components of which are the education of fear of sin, overcoming passions, contemplation, acceptance of Christ in the fullness of love for him, and others. An important aspect of hesychasm is his interpretation of human deification as synergy. Theosis presupposes an actual combination of the energy of man and God, their cooperation (Kletsova, 2003: 41). That is, in the divine grace the will of man is completely dissolved (Kletsova, 2003: 42).

S. Khoruzhiy notes that the main task of asceticism is to achieve grace. Next are the higher stages, at which its action becomes predominant. Gradually, grace begins to prevail more clearly over the actions of the natural, purely human. The real transformation of man begins. In the finale, at the highest rungs of the Stairs, hesychastic rigor leads to the fact that the 
Orthodox tradition means «deification», theososis, the perfect union of man with God in His energies, synergy. The experience of being at the highest rungs of the Stairs for hesychasts is the experience of contemplating the «Tabor light». This vision, characteristic of the theology of Gregory Palamas and the decision of the ecclesiastical councils, testified that the ascetic experience is indeed the experience of deification, which presupposes the complete union of the divine and the human, which is manifested in the man of Christ. The Transfiguration on Mount Favor is an evangelical sacred event in which hesychasm sees a connection, a combination of a specifically ascetic path with a church-wide, all-Christian way (Khoruzhiy, 2005: 130-131).

The spiritual ascent of man consists in the synergetic union of his and the Divine energies, as a result of which the latter grow into the likeness of God and there is a complete revelation of the human personality. Accordingly, during theosis in hesychasm a new «energy image» of man is built, in which it is no longer seen as a self-sufficient substance, but exists in the direction of God and connection with Him. Note that as a person approaches God, His Name becomes more and more characteristic of him, and he begins to embody this Name in himself more and more. Then the complete separation of the Name from man leads to its destruction and transformation into nothingness (Sidorina, 2014: 52).

Thus, cognition through the heart is defined in hesychasm as "reasonable vision", "reasonable action". And the most important moment of this "act" is considered to be the "introduction of the mind into the heart", because the essence and content of hesychia were interpreted as a mysterious and suprarational work to rebuild the soul into a state of readiness to receive grace (Nenya, 2006).

\section{Ideas of hesychasm in the representatives of the Ukrainian Middle Ages}

Note that hesychastic ideas of godlikeness and deification of man appear in Ukraine against the background of historical and philosophical context formed by the ancient idea of the ratio of macro- and microcosm, as well as the Christian tradition of dichotomous division into divine and creative life. The first theoretical sources on the basis of which thinkers of medieval Ukraine made their own philosophical generalizations, conclusions about God, the universe and man, were the works of Eastern patristic (John of Damascus, Dionysius the Areopagite, later - Gregory of Sinai and Gregory Palamas). A special role here was played by the Christian idea of deification, the embodiment of which was hesychasm. Some of its elements are found in the period of Kievan Rus, and the peak of popularity falls on the XIV-XVI centuries.

Note that the translations of John Chrysostom, who focused on the ethical and religious content of the Gospel and was a teacher of charitable love agape in its social aspect (protected the poor and exposed the rich), were very popular among the ancient $n$ educated population. Ephraim Sirin (IV century) was no less popular. His poetic works are characterized by biblical lyricism and moods of repentance. Ephraim Sirin attached great importance to prayer, 
which is an inexhaustible treasure trove of many boons. He noted that prayer has a psychotherapeutic effect. After all, if the anguish of the soul is inside, it suppresses thoughts, and when it comes out through prayer, then it brings great clarity to the soul. Sirin equates prayer to a tree that is deeply rooted in the earth and is not afraid of any gusts of wind. All the spiritual and ethical guidelines of Ephraim Sirin are permeated by the following idea: the deeper a person's grief over the humiliation of the Divine image, the more thorough is its self-purification and restoration of the true state, the more real is the knowledge of God through revelation (Predko, 2005).

By interpreting the essence of the interaction of heart, mind, soul and Spirit, man has historically formed the specifics of hesychasm as a mystical branch of Orthodox Christianity, conceptually outlined its basic worldview principles, formed a philosophical and theological theoretical basis for the future, domestic version of «philosophy of the heart» (Nenya, 2005). After all, in contrast to the Western European tradition of mystical philosophy, hesychasm builds a worldview and understanding of the world beyond the scientific, logical and theoretical achievements of philosophy and rationalist thinking, cultivating mystical enlightenment, or or mystical visions as the main method of knowing the world and the universe, knowing the reality and essence of the processes that take place in it, as a method of possible "entry», recognition or «disclosure» of the meaning of symbolics through which this reality is reproduced in the human mind (Zuban, 2008).

The process of cognition, which is a necessary component of theosis, was considered the interpretation of the truth expressed in the Logos. The world was perceived as a book containing the truth commanded by God, which man must understand. That is why the ancient Russian style of thinking is dominated by «cognitive» vision of the world. The scribes of Kievan Rus, like the Byzantine and South Slavic scribes, saw the word more as a way to symbolize the world and, through «intelligent» prayer, as a mystical fusion with God. This understanding of the word is seen in the works of the allegorical nature of ancient $\mathrm{n}$ scribes (Metropolitan Hilarion, Clement Smolyatych, etc.) (Batsevych, 2000: 147).

Regarding the commitment of representatives of Ukrainian philosophical thought of the late XVI - early XVII centuries to the ideas of hesychasm and Neoplatonism should be noted: the ideas of Neoplatonism were based on M. Smotrytsky, K.-T. Stavrovetsky, L. Zizaniy, K. Sakovich; and the positions of the philosophy of hesychasm were held, in particular, by Iov Pochaivsky, Iov Knyagynetsky, Isaiah Kosynsky, and most of all by Ivan Vyshensky (Kletsova, 2003: 44). It is noteworthy that, since both Neoplatonism and hesychasm coincide significantly in the question of the need for the theosis of human free will, its implementation requires from man the greatest possible manifestations of free will (Kletsova, 2003: 43). Also virtually identical for hesychasts and Neoplatonists are the deep meaning of the inner mystical experience and the vision of the state of 
ecstasy as the most complete manifestation, the limits of the mystical spiritual path to theosis (Kletsova, 2003: 44).

In particular, G. Smotrytsky's worldview unites with hesychasm that he preaches the need for self-absorption during prayer. After all, the means of bringing man closer to God, the way to "discover" in himself the inner man, which is a reflection of God - deification - is focused prayer in solitude (Levchenko, 2018: 187).

\section{CONCLUSIONS}

Thus, analyzing the views of the Ukrainian Middle Ages and early modern times on the path of human spiritual development through hesychasm, we conclude that they were characterized by the vision of deification as a person's approach to God through self-reflection and moral improvement (Kendus, 2010: 73). This is the main purpose of human life. This concept is considered fundamental to the theology of holiness. Its essence is in the restoration by man of the image of God and His likeness. The path to the knowledge of God in hesychasm is identified with the ascetic renunciation of passions and worldly pleasures. The way to union with God opens to man the combination in him of the Divine and human natures. According to the dogmas of the Eastern Church, theos, which is a state of subjective experience of the human person, is the ultimate goal of the restoration of humanity. Hesychasm sees this as a synergy - an interacting combination of the energy of man and God. The main task of austerity is the achieving of grace. This dissolves the human will in the process of human transformation. The doctrine of theosis had an impact on the formation of the theocratic idea in the culture of Rus. In understanding oneself as the image of God, the wisdom play an important role. Deification is the end result on the path of self-knowledge for the representatives of philosophical thought of the Middle Ages and early modernism, who attached special importance to the inner mystical experience and sought to experience spiritual ecstasy as the limit of the mystical path to theosis.

It should be emphasized that hesychasm, as a specific branch of GrecoByzantine Christian theology, illustrates more than a thousand years of practice and theological theory of the development of a religious-ideological concept based on the idea of deification of the human being. It is the practice of trying to transform its existence in accordance with the ideals of humanism of the Orthodox Church.

In our opinion, historical-philosophical and philosophical-anthropological studies on the proposed topics are promising, as they allow not only to trace the peculiarities of the formation of national mentality, but also to outline a number of problems relating to moral and ethical principles of humanity in general. У подальших наукових пошуках плануємо поглибити дослідження станів переживання містичного досвіду представниками Українського Середньовіччя та ранньомодерного періоду. 
In further scientific research, we plan to deepen the study of the state of feeling of mystical experience by representatives of the Ukrainian Middle Ages and early modern period.

\section{SUMMARY}

In the article the author considers the role of hesychasm in the selfdevelopment of the individual, which occurs through religious spiritual pursuits. It is noted that hesychasm, as a spiritual practice, was a forerunner of the «philosophy of the heart». Its role in the formation of national spiritual values is also traced. The author tries to analyze the vision of the path of spiritual formation in the philosophical and religious views of the Ukrainian Middle Ages in the context of the doctrine of theosis. As a state of subjective experience of the human personality, theosis is considered in hesychasm, which interprets it as a synergy - an interacting combination of energies of man and God. Followers of hesychasm believe that theosis is the experience of the subjective experience of the human person, synergy is the interacting combination of the energy of man and God. The doctrine of theosis had an impact on the formation of the theocratic idea in the culture of, in which the wisdom play an important role in self-awareness as an image of God. Theosis is the end result on the path of spiritual growth for the representatives of philosophical thought of the Middle Ages and early modernism, who attached deep importance to gaining inner mystical experience and sought to experience spiritual ecstasy as the ultimate goal in the mystical path to deification. In the article, the author emphasizes that the activity-moral life presupposed the maximum possible fulfillment of one's life purpose, which was considered as deification and service to one's neighbor. Analyzing the views of the Ukrainian Middle Ages on the spiritual development of man through hesychasm, the author concludes that they were characterized by the vision of deification as a person's approach to God through self-knowledge and moral improvement. The relevance of this method of self-development in today's conditions is noted.

\section{REFERENCES}

1. Babii V. (2013). Vchennia pro teozys (obozhennia) u tvorakh prepodobnoho Symeona Novoho Bohoslova: khrystolohichnopnevmatolohichnyi aspekt: avtoref. dys. kand. bohosl. Nauk [The doctrine of theosis (deification) in the works of St. Simeon the New Theologian: Christological and pneumatological aspect]. Kyiv: Kyiv. pravoslav. bohosl. akad. Ukr. Pravoslav. Tserkvy Kyiv. Patriarkhatu. 22 s. [in Ukrainian]

2. Batsevych F. (2000). Shliakhy rozvytku filosofii movy u skhidnykh slovian: vizantiiski ta pivdennoslovianski vplyvy [Ways of development of philosophy of language in Eastern Slavs: Byzantine and South Slavic influences]. Problemy slovianoznavstva. Vyp. 51. S.143-148. [in Ukrainian] 
3. Hlushchenko A. (2013). Znachenye antropolohyy prepodobnoho Maksyma Yspovednyka dlia sovremennoi pravoslavnoi apolohetyky [The importance of the anthropology of the Monk Maximus the Confessor for modern Orthodox apologetics]. Kyevskaia dukhovnaia akademyia y semynaryia. Kyiv: Yzdatelskyi otdel Ukraynskoi Pravoslavnoi Tserkvy. 295 s. [in Russian]

4. Zuban H. (2008). Antropolohichna tsilisnist: problema podolannia rozirvanosti liudskoho buttia u mistychno-dukhovnii praktytsi isykhazmu [Anthropological integrity: the problem of overcoming the rupture of human existence in the mystical and spiritual practice of hesychasm]. Noosfera $i$ tsyvilizatsiia. Vyp. 6 (9). S. 230-242. [in Ukrainian]

5. Kendus O. (2010). Samorefleksiia osobystosti u filosofsko-relihiinomu svitohliadi predstavnykiv ukrainskoho kliru [Self-reflection of personality in the philosophical and religious worldview of the Ukrainian clergy]. Sotsiohumanitarni problemy liudyny. № 4. S. 71-79. [in Ukrainian]

6. Kletsova S. (2003). Tradytsii mistytsyzmu v konteksti ukrainskoi khrystyianskoi filosofii kintsia XVI-pochatku XVII st [Traditions of mysticism in the context of Ukrainian Christian philosophy of the late XVI-early XVII centuries]. Nauka. Relihiia. Suspilstvo. IPShI «Nauka i osvita». № 4. S.40-45. [in Ukrainian]

7. Levchenko N. (2018). Bibliina hermenevtyka v davnii ukrainskii literaturi [Biblical hermeneutics in ancient Ukrainian literature]. Kharkiv: Maidan. 392 s. [in Ukrainian]

8. Lysenko O. (2016). Favorske svitlo yak smysloobraz pravoslavnoho idealu liudyny [The «Tabor light» as a Semantic Orthodox Ideal of Man.]: avtoref. dys. kand. filos. nauk: 09.00.11. Zhytomyr. derzh. un-t im. Ivana Franka. Zhytomyr. $16 \mathrm{~s}$. [in Ukrainian]

9. Nenia H. (2005). "Filosofiia sertsia" Hryhoriia Palamy yak dzherelo istoryko-kulturolohichnykh vytokiv dukhovnoi kultury Ukrainy [«Philosophy of the Heart» by Hryhoriy Palama as a source of historical and culturological origins of the spiritual culture of Ukraine]. Dukhovna kultura yak dominanta ukrainskoho zhyttietvorennia. Zbirnyk materialiv Vseukrainskoi naukovopraktychnoi konferentsii. P. 1. Kyiv: DAKKKiM. S. 82-84. [in Ukrainian]

10. Nenia H. (2006). Isykhazm yak spetsyfichna pravoslavna svitohliadnobohoslovska kontseptsiia mistychnoi filosofii khrystyianstva [Hesychasm as a specific Orthodox worldview and theological concept of the mystical philosophy of Christianity]. Multyversum. Filosofskyi almanakh. Vyp. 53. S. 88-97. [in Ukrainian]

11. Nenia H. (2007). Mistychni dosvid i praktyka v kontseptsii obozhennia (istoryko-filosofskyi analiz tradytsii isykhazmu) [The mystic experience and practice in the concept of goddening (the historic and philosophical analysis of the Hesychasm tradition)]: avtoref. dys. kand. filos. nauk: 09.00.05. In-t filosofii im. H.S.Skovorody NAN Ukrainy. Kyiv. 15 s. [in Ukrainian] 
12. Predko O.I. (2005). Molytva yak chynnyk dukhovnosti: bohoslovski ta filosofski vymiry [Prayer as a factor of spirituality: theological and philosophical dimensions]. Nova paradyhma: Filosofiia. Sotsiolohiia. Politolohiia. Kyiv: Vyd-vo NPU imeni M.P. Drahomanova. Vyp. 42. S. 22-32. [in Ukrainian]

13. Sidorina Ye. (2014). Filosofskyi dosvid osmyslennia liudyny v isykhazmi [Philosophical experience of human comprehension in hesychasm]. Mizhn. nauk. konf. «Dni nauky filosofskoho fakultetu - 2014», 15-16 kvit. 2014 r. Kyiv: Vydavnycho-polihrafichnyi tsentr «Kyivskyi universytet». Ch. 1. S.50-53. [in Ukrainian]

14. Telizhenko L.V. (2002). Mystycheskyi opyt dukhovnoi praktyky ysykhazma: synerhetycheskyi podkhod [The mystical experience of the spiritual practice of hesychasm: a synergetic approach]. Studia methodologica: Almanakh naukovykh prats. Vyp. 12. S. 12-16. [in Russian]

15. Telizhenko L.V. (2004). Mistychnyi dosvid yak antropolohichnyi modus [Mystical experience as an anthropological mode]: avtoref. dys. na zdobuttia nauk. stupenia kand. filos. nauk: spets. 09.00.04 «Filosofska antropolohiia, filosofiia kultury». Kharkiv. $18 \mathrm{~s}$. [in Ukrainian]

16. Khoruzhyi S. (2005). Ocherky synerhyinoi antropolohyy [Essays on synergistic anthropology]. Moscow: Ynstytut fylosofyy, teolohyy y ystoryy sv. Fomy. 408 s. [in Russian]

17. Chornomorets Ye.M. (2019). Teoretychni osnovy khrystyianskoneoplatonichnoi estetyky Maksyma Spovidnyka [Theoretical foundations of Christian Neoplatonic Aesthetics of Maximus the Confessor: historical and philosophical analysis] : istoryko-filosofskyi analiz: avtoref. dys. kand. filos. nauk: 09.00.05. Nats. ped. un-t im. M.P. Drahomanova. Kyiv. 19 s. [in Ukrainian]

\section{Information about the author:} Hudzenko O.,

Candidate of Philosophical Sciences, Associate Professor, Associate Professor at the Department of World History and Philosophy,

Lesya Ukrainka Volyn National University 13 Voli ave., Lutsk, Volyn region, 43025, Ukraine 